\title{
Romeine 1:26-27: Evaluering van eksegetiese en hermeneutiese argumente in die debat oor selfdegeslagverhoudings
}



Romans 1:26-27 plays an important role in the same sex relationships debate. The present study is a review article and focuses on all the important pro same sex relationships arguments vis-à-vis this text, that is, those exegetical and hermeneutical arguments that relativize the relevancy of this text for the debate. Furthermore, in this debate a sharp distinction is not always drawn between exegetical and hermeneutical insights. The article aims at rectifying this deficiency. First the true exegetical arguments are identified and evaluated, and thereafter the hermeneutical insights. The conclusion is that, in this case, it is not the exegetical arguments that are decisive, but the hermeneutical insights.

\section{Inleiding ${ }^{1}$}

Die Algemene Sinode van die NG Kerk het in Oktober 2015 die verreikende besluit geneem dat gays toegelaat word tot die amp van bedienaar van die Woord in die NG Kerk sonder dat hulle selibaat hoef te bly en dat burgerlike verbintenisse tussen gay-lidmate kerklik bevestig mag word (vir die volledige besluit, kyk Algemene Sinode NG Kerk 2015). Dit het 'n hewige polemiek in die kerklike en openbare media tot gevolg gehad - in so 'n mate dat sommige kerkrade en lidmate appèl teen die besluit aangeteken het en die NG Kerk se Moderamen die in werking stelling van die besluit opgeskort het tot die volgende Algemene Sinode in 2017. ${ }^{2}$

In die selfdegeslagverhoudingsdebat (voortaan aangedui as 'debat') speel die interpretasie van Romeine 1:26-27 'n belangrike rol. ${ }^{4}$ Dit is derhalwe die oogmerk van dié artikel om op hierdie teks te fokus. Die studie neem die vorm van 'n oorsigartikel aan. Eers word daar op die belangrikheid van die onderskeid tussen eksegese en hermeneutiek vir die onderhawige onderwerp gefokus. Daarna kom die eksegetiese argumente aan die orde wat almal op die oog het om die relevansie van 1:26-27 vir die debat te relativeer of te elimineer, dit wil sê argumente wat ten gunste van selfdegeslagverhoudings is en betoog dat hierdie teks nie in die hedendaagse debat gebruik kan word om teen mense met 'n homoseksuele oriëntasie te diskrimineer nie. Laastens word die hermeneutiese insigte beoordeel wat, na my oordeel, die deurslaggewende moment in die debat is.

\section{Onderskeid tussen eksegese en hermeneutiek}

In die debat is daar duidelike eksegetiese en hermeneutiese argumente hoewel daar nie altyd skerp tussen hierdie twee kategorieë onderskei word nie. Uiteraard is eksegese en hermeneutiek twee kante van dieselfde muntstuk: dit bepaal mekaar oor en weer. Dit behoef geen betoog dat mens altyd eksegese vanuit 'n bepaalde verstaansraamwerk en met sekere (bekende óf verskuilde) vooronderstellings doen nie. Dit is dus onteenseglik dat sogenaamde suiwer eksegetiese resultate dikwels die uitkoms van bepaalde hermeneutiese vertrekpunte is, veral in

1.Hierdie bydrae word met groot erkentlikheid opgedra aan my jarelange vriend en kollega, Fika Janse van Rensburg. Ons het oor die jare aan vele projekte saamgewerk, en telkens was ek onder die indruk van sy wetenskaplike erudisie en onkreukbare integriteit as mens. Ek vertrou dat hierdie bydrae Fika se belangstelling sal prikkel, aangesien hyself, in samewerking met ' $n$ kollega, enkele jare gelede sy hand aan hierdie onderwerp gewaag het (vgl. Botha \& Janse van Rensburg 2004).

2.Reeds in 2006 was die debat oor homoseksualiteit so hewig dat Du Toit (2006:452-454) pleit dat mede-Christene wat teenoorstaande standpunte huldig, mekaar nie sal verketter nie, maar met liefde en respek sal hanteer. Du Toit lewer hierdie pleitrede teen die agtergrond van Paulus se hantering van die sogenaamde swakkes en sterkes in Romeine 14. Met hierdie pleitrede sê Du Toit implisiet dat homoseksualiteit nie 'n kerngeloofstuk is nie, maar' $n$ randsaak waaroor Christene maar kan verskil.

3.Verdere verwysings na die brief aan die Romeine sal slegs met hoofstukke en verse aangedui word.

4. Uiteraard is die interpretasie van die ander Bybeltekste waar homoseksualiteit (na bewering) voorkom (Gen 19:1-11; Lev 18:22; 20:13; Rig 19:22-24; 1 Kor 6:9-10; 1 Tim 1:10) ook ter sprake, maar 1:26-27 neem 'n sentrale plek in (Du Toit 2007:164), omdat dit in die Nuwe Testament die duidelikste teks is oor homoseksuele aktiwiteit (Steyn 2007:190). 
hierdie debat. Tog is ek van mening dat eksegese en hermeneutiek so ver moontlik as twee onderskeie bewegings in die interpretasieproses hanteer moet word. $\mathrm{Al}$ is dit bykans onmoontlik om 'n mens se vertrekpunte, voorliefdes en vooroordele op te skort - selfs net tydelik - lê 'n hermeneutiek wat die teks vooropstel die verpligting op die eksegeet om so onbevange as moontlik te luister na wat die teks self sê. Eers dan, as 'n tweede beweging, kan die eise van die eietydse konteks 'n rol speel in die verstaan en toepassing van die teks vir vandag.

In die huidige debat verkeer hierdie ideale werkwyse egter onder groot druk, want dit is juis die eietydse insigte rakende homoseksualiteit wat uit die staanspoor 'n bepalende rol speel. Dit veroorsaak ook dat ons die bekende tekste wat homoseksualiteit oënskynlik afwys met nuwe oë bekyk en met'n soort hermeneutiek van suspisie benader. Indien mens reeds op ander gronde oortuig is dat homoseksualiteit 'n komplekse verskynsel is en nie so maklik as 'sonde' of 'teen die wil van God' afgemaak kan word nie, is daar 'n ingeboude verwagting dat die tekste iets anders moet sê as wat hulle inderdaad sê. Die vertrekpunt is dan die volgende: sê hierdie tekste regtig wat dit op die klank af sê? Met hierdie 'suspisie' word die tekste dan gelees. Die omgekeerde is egter ook waar: maak die oënskynlik klinkklare taal van die teks ons nie juis bevooroordeeld in ons verstaan van 'n komplekse eietydse verskynsel omdat dit aansluiting vind by 'n aangebore aversie aan alles wat vreemd is nie? Tree ons homofobiese geneigdheid nie onmiddellik na vore nie? Versterk die op-die-klank-af-lees van hierdie tekste nie die vooroordele van die dominant heteroseksuele narratief met al sy innuendo's en skunnighede nie? Maak hierdie soort lees van die teks nie dat ons gays en die klinies-wetenskaplike argumente rondom homoseksualiteit nie regtig ernstig opneem nie? Dwing die respek vir die gesag van die Bybelteks ons nie dalk daartoe om op 'n fundamentalistiese manier gesagvolle antwoorde te gee vir 'n situasie wat nie direk in die Bybel hanteer word nie? Laastens, wat presies is die gesagvolle Woord van God wat vandag oor hierdie saak deurgegee moet word? Dit maak nie saak hoe ernstig die kerk die gesag van die Bybel neem en hoe vas ons staan op die sola Scriptura-beginsel nie, die feit van die saak is dat die interpretasie van die Skrif nooit in 'n vakuum plaasvind nie (Hays 1996:209). Selfs al is daar helder en duidelike tekste in die Bybel oor bepaalde aangeleenthede wat geen twyfel laat oor die betekenis daarvan nie, ${ }^{5}$ worstel die kerk steeds om die gesag daarvan eietyds toe te pas soos eweneens die kwessie van homoseksualiteit.

Desnieteenstaande die vervlegdheid van eksegese en hermeneutiek is ek tog van mening dat ' $n$ mens nie die ideaal moet laat vaar om dit afsonderlik te hanteer nie, veral in hierdie debat. Juis hier moet mens goed na die bedoeling van die teks luister (eksegese), maar hierdie bedoeling dan in gesprek laat tree met breër hermeneutiese moontlikhede wat mag onderrig gee in die kerk nie (1 Tim 2:11-12); dat vroue hulle koppe moet bed
(1 Kor 11:2-16); en dat Christene mekaar se voete moet was (Joh 13:14-15). verantwoordelike en dinamiese Skrifverstaan bied. ${ }^{6}$ In hierdie debat is dit van kritiese belang dat daar uiteindelik geen onduidelikheid sal wees op watter gronde ' $n$ mens na die een of ander kant toe besluit nie. 'n Mens moet veral nie voorgee dat jou keuses suiwer op eksegetiese gronde gemaak word terwyl dit eintlik hermeneutiese oorwegings is wat die skaal laat swaai nie. Om hierdie rede sal daar in hierdie bydrae eers 'n evaluering van die eksegetiese argumente gedoen word op grond waarvan navorsers beweer dat 1:26-27 nie ' $n$ deurslaggewende bydrae tot die huidige debat maak nie. Daarna sal die hermeneutiese argumente aan die bod kom. Hopelik lewer hierdie werkwyse die bydrae dat 'n mens minstens groter helderheid het presies op grond waarvan jy vír of téén 'n besluit soos dié deur die NG Kerk geneem standpunt sou inneem.

\section{Eksegetiese argumente}

In hierdie afdeling word die eksegetiese argumente rakende 1:26-27 wat pro-selfdegeslagverhoudings is aan die orde gestel. Daar word nie aanspraak op volledigheid gemaak nie hoewel die argumente wat aan die bod kom na my mening 'n goeie oorsig van die vernaamste argumente in die debat gee. Hier en daar mag oorvleueling voorkom, maar die bedoeling is om telkens 'n spesifieke beklemtoning in die argumentasie te belig. Weens die beperkte omvang van hierdie bydrae sal daar uiteraard nie volledig op elke argument uitgebrei kan word nie - slegs die hoofsake sal uitgelig word. Daar sal ook telkens 'n kort evaluering gebied word van die relatiewe eksegetiese waarde wat elke argument tot die debat bydra.

\section{Die argument van Romeine 1 relativeer Romeine 1:26-27 se eksegetiese waarde vir die debat}

Die heel basiese eksegetiese vereiste is om vas te stel binne watter groter argument ' $n$ bepaalde teksgedeelte funksioneer. 'n Aanvaarbare indeling is dat 1:26-27 binne die groter eenheid van 1:18-3:20 tereg kom (kyk bv. Du Toit 2003:95; Loader 2014:3). Die argument wat Paulus hier met sy gemengde gehoor van Joodse en heiden-Christene voer, waarvan laasgenoemde waarskynlik in die meerderheid was (vgl. DeSilva 2004:600; McDonald \& Porter 2000:454), is dat die ganse mensdom strafwaardig voor God is - daar is nie een wat goed doen nie (3:19). Almal het dus eweveel nood aan die vryspraak van God wat Christus bewerk het. Om hierdie punt te beredeneer, voer Paulus in 1:18-3:20 'n argument van 'gelykstelling' waar heiden- en Joodse Christene oor dieselfde kam geskeer word (Witherington 2004:58-59). Nie een van hierdie groepe kan op onskuld voor die aangesig van God aanspraak maak nie. Om hierdie punt tuis te bring, handel Paulus vervolgens eers oor die sondes van die heidene (1:18-32). In breë trekke word die verwording van die heidene beskryf. Die argument verloop in twee fases.

6.In hierdie artikel word die volgende onderskeiding tussen eksegese en hermeneutiek gemaak: Eksegese verklaar die teks in sy historiese en literêre bedding. So probeer ons afstand kry van die teks in sy historiese andersheid sodat dit nie sê wat ons daarin projekteer nie, maar aan ons meedeel wat dit self wil sê. Hermeneutiek laa die teks vandag tuiskom, inkorporeer dit in ons eie wêreld op 'n kognitiewe en eksistensiële manier. So word die betekenis van die teks geïntegreer met die wêreld van die leser en deur hom of haar toegeëien (vir hierdie onderskeiding kyk Schneiders 1999:17, 123-124, 126). 
In die eerste fase (1:18-23) verduidelik Paulus hoe die nasies die eerste gebod oortree: ten spyte daarvan dat hulle uit die natuur kan agterkom wie God is, verkies hulle om Hom nie as God te erken nie. In die plek van die onverganklike God aanbid hulle beelde (afgode) van verganklike mense of diere, en so oortree hulle ook die tweede gebod. Die tweede fase (1:24-32) beskryf God se reaksie hierop. Drie keer word genoem hoe God die nasies 'oorgegee het' ( $\pi \alpha \rho \varepsilon ́ \delta \omega \kappa \varepsilon v)$ aan hulle eie begeertes $(1: 24,26,28)$. Die eerste manifestasie hiervan is dat hulle die natuurlike omgang tussen mans en vroue verruil het vir die teen-natuurlike. Drie keer word hierdie taal van 'omruiling' of 'verandering' ( $\dot{\alpha} \lambda \dot{\alpha} \sigma \sigma \omega /$ $\mu \varepsilon \tau \alpha \lambda \alpha \dot{\sigma} \sigma \sigma \omega)$ van God se orde gebruik: ${ }^{7}$ die eer wat God toekom, word omgeruil vir eerbied aan 'n afgod (1:23); die waarheid word omgeruil vir die leuen (1:25); en die natuurlike seksuele omgang word omgeruil vir die teen-natuurlike (1:26). Hieruit blyk die oordeel van God oor die nasies. Dat God se orde, waaronder die seksuele, deur die mens geperverteer word, is egter nie die oorsaak van God se oordeel nie, ${ }^{8}$ maar die gevolg daarvan (Jewett 2007:173; Schreiner 1998:91). Niks erger kan gebeur as dat God jou oorgee aan jou sonde nie. So hou die mens se ruiltransaksie met God, waar die waarheid vir die leuen ingeruil word, sy eie straf in (Du Toit 2003:96).

Verder kom daar twee sondelyste voor in die tweede fase van Paulus se argument (1:24-32) waar die sondes van die heidene gelys word. Die eerste (1:24-27) is reeds bespreek, naamlik die inruiling van die natuurlike seksuele orde vir die teen-natuurlike wat deur die Jode as tipiese heidense perversiteit beskou is (Dunn 1988:65; Hultgren 1994:315-316; Wilckens 1980:110). Die tweede lys (1:29-31) is die meer algemene sondes waarvoor heidene ook bekend was, naamlik ongeregtigheid, slegtheid, hebsug, moord, bedrog, ensovoorts. Nolland (2000:43) wys daarop dat Paulus doelbewus die tweede sondelys meer algemeen maak om ook die Jode by die sondes van die heidene in te sluit. Waarby Paulus dus wil uitkom, is om in Romeine 2 ook die Jode by die oordeel van God te betrek - dat hulle aan dieselfde dinge skuldig is waarvan hulle die heidene beskuldig. Die voortgang na die Jode word in 2:1 duidelik gemaak met die

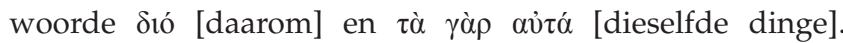
Laasgenoemde frase kan vooruit wys na argumente wat Paulus nog sal noem om die Jode op gelyke basis te betrek by die oordeel van God (so Jewett 2007:198), maar dit kan ook terugverwys na veral 1:29-31 waar die sondes van die heidene juis so algemeen beskryf is om die oorgang na Romeine 2 te bewerkstellig waar die Jode ook onder God se oordeel ingetrek word (kyk Nolland 2000:43). Hoe dit ook al sy, die feit is dat heiden sowel as Jood op gelyke vlak verkeer as dit by strafbare sondes voor die aangesig van God kom. Geen mens - nie heiden of Jood nie - kan hom- of haarself voor God verontskuldig nie. Daarom het almal ook eweveel nood aan die redding in Christus.

7.Hultgren (1994:318) noem dat 1:23-32 se struktuur opgebou is rondom die werkwoord verander en oorgee.

8. Dit sou lei tot ' $n$ moralisering van die verhouding met God waar God bloot op mense se goeie of slegte gedrag reageer.
Uit hierdie beskrywing van die argument van Romeine 1 kan die volgende afleidings ten gunste van selfdegeslagverhoudings gemaak word:

- Die hoofargument is nie op homoseksuele dade as sodanig gerig nie. Die hoofdoel is om die verwording van alle mense voor die aangesig van God te beklemtoon, nie om die Jode superieur te laat voel teenoor die heidene nie (Achtemeier 1985:41). Paulus is dus nie daarop uit om 'n seksuele etiek - in die algemeen of oor homoseksuele praktyke spesifiek - te verskaf nie. Hy maak eerder van standaard-sondelyste gebruik ${ }^{9}$ om met breë kwasstrepe die tradisionele sondes van die heidene voor te stel. Homoseksuele dade word dus insidenteel betrek as een van die baie sondes van die heidene (vgl. Nolland 2000:34; Loader 2014:4). Die feit dat daar twee sondelyste wat ook baie ander sondes bevat in Romeine 1 voorkom, is ' $n$ duidelike aanduiding hiervan. Ook in die ander sondelyste waar homoseksuele dade opduik soos 1 Korintiërs 6:9 en 1 Timoteus 1:9-10, is dit één sondige praktyk tussen baie ander. Bloot vanuit die argument in Romeine 1 moet dus minstens gesê word dat homoseksuele dade nie 'n groter sonde is as ander nie.

- Vanuit die plasing van homoseksuele dade in 1:18-32 moet ook 'n opmerking gemaak word. Die feit dat dit eerste in hierdie perikoop genoem word, beteken nie dat dit as ' $n$ erger sonde as ander gebrandmerk moet word nie. In die sondelys van 1 Korintiërs 6:9 word dit nie eerste genoem nie (ook nie in 1 Tim 1:9-10 nie). Verder is daar'n voor die hand liggende rede waarom homoseksuele verhoudings in Romeine 1 eerste genoem word en ook waarom vroulike homo-erotiek voor dié van mans beskryf word. Dis omdat dit die mees opvallende voorbeeld is van die omkering van die Goddelike orde en nie omdat dit vir Paulus ' $n$ groter sonde is as die ander nie (Du Toit 2003:96, 98).

- Uit die vorige twee afleidings word 1:26-27 dan gewoonlik vir die debat gerelativeer, indien nie geëlimineer nie. Toegegee, die manier waarop homoseksuele dade binne die groter argument van 1:18-3:20 aan die orde gestel word, suggereer wel dat hierdie praktyk nie deur Paulus as 'n groter sonde as ander beskou word nie. Die literêre plek van 1:26-27 in die groter argument is egter nie op sy eie voldoende om te besluit dat dit die rede is waarom dit geen eksegetiese gewig vir die debat inhou nie. Daarvoor is die inhoud van die teks (die tipering van homoseksuele dade as contra naturam, 'skandelik' en 'pervers') te prominent. Hierdie kwessies word egter deur die onderstaande eksegetiese argumente hanteer en daaruit word 1:26-27 dan gewoonlik gerelativeer vir die debat.

\section{Homoseksuele dade moet beperk word tot tempelprostitusie in die konteks van afgodery}

Dit is so dat die sondelyste van 1:18-32 binne die groter argument van die mens se totale verdorwenheid gesien moet word. Op sy beurt word hierdie verdorwenheid

9.Witherington (2004:63) en Jewett (2007:174) wys op die treffende ooreenkomste tussen Romeine 1 se beskrywing van heidene wat God se natuurlike orde omkeer en tussen Romeine 1 se beskrywing van heidene wat God se natuurlike orde omkeer en
soortgelyke beskrywings in Joodse bronne soos die Wysheid van Salomo 14:26 (en ander plekke) en die Testament van Naftali 3:3-4. 
verstaan as die resultaat van afgodery waar die mens die ware diens aan God vir die diens aan afgode verruil het (1:23). Die gevolg is dat God die mens aan sy eie welluste, waaronder homoseksuele dade, oorgegee het (1:24). Sommige voorstanders van selfdegeslagverhoudings redeneer vervolgens dat 1:26-27 niks met die huidige verstaan van homoseksualiteit te doen het nie, omdat die homoseksuele dade waarvan hier sprake is, beperk moet word tot wat in die antieke afgodstempels beoefen is. Hierdie dade moet dus as uitdrukking van afgodsdiens, en meer spesifiek as die beoefening van tempelprostitusie $\mathrm{e}^{10}$ gesien word. Omdat hierdie konteks nie meer vandag vir homoseksuele geld nie, is 1:26-27 nie relevant vir die huidige debat nie (vir outeurs met hierdie standpunt, kyk Malick 1993:333; Lenow 2006:33-34).

Eksegeties kan dit nie ontken word nie dat afgodery die breë agtergrond vorm vir die sondelyste van 1:18-32, waaronder dan ook homoseksuele dade. Daar is egter gewigtige argumente om die homoseksuele dade van 1:26-27 nie tot tempelprostitusie te beperk nie. Die volgende kan genoem word (ontleen aan Du Toit 2003:102):

- Paulus veroordeel homoseksuele dade in sulke algemene terme dat dit nouliks tot die kultiese sfeer beperk kan word.

- Paulus se kritiek is dat homoseksuele dade teennatuurlik

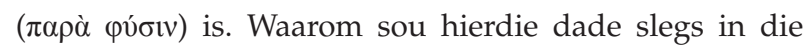
kultus teennatuurlik wees en nie daarbuite nie?

- Die meeste Griekse moraal-filosowe van die antieke tyd veroordeel alle homoseksuele dade - nie net dié wat in die kultus beoefen is nie. Sou Paulus minder sensitief wees as die moraal-filosowe deur slegs tempelprostitusie te veroordeel?

- Waarom sou slegs die sondelys van 1:26-27 tot die kultus van heidentempels beperk word, maar nie ook die sondige dade van 1:29-31 nie? Indien eersgenoemde beperking die bedoeling was, sou daar duidelike teksaanduidings gewees het.

- Paulus is besig om in breë trekke die morele verval van die heidene te beskryf in terme van 'n teologiese 'oersonde', naamlik afgodery. Dit beteken egter nie dat elke immorele daad soos byvoorbeeld homoseksuele dade direk aan tempelprostitusie gekoppel kan word nie. Dit sou die argument te ver voer. Dit is waarskynlik beter om soos Lenow (2006:36) te sê dat die verhouding tussen afgodery en homoseksuele dade een van breë ooreenkoms is. Die heidene het die regte verhouding met God skeefgetrek deur afgode te aanbid. Net so word die regte seksuele verhoudings skeefgetrek deur teennatuurlike homoseksuele dade uit te voer (vgl. ook Malick 1993:335).

10.Tempelprostitusie het wydverspreid in die antieke heidentempels voorgekom beide in die vorm van hetero- en homoseksuele dade. Afgodsdiens en tempelprostitusie het dus hand aan hand gegaan. Townsley (2013) wys verder daarop daarop dat die vroee kerkaders, waaronder Hipolitus, Pelagius en Origenes 1:2627 nie in terme van seksualiteit aangehaal het nie, maar om bedenklike fgodsdienspraktyke te beveg. Die voorkoms van die sogenaamde galli of wekastreerde priesters wat diens gedoen het as manlike prostitute in die tempels wat aan godinne gewy was, was ter sprake. Dit sou as versterking kon dien van die standpunt dat Paulus se primêre verwysing hier na tempelprostitute - mans of vroue - was.
Die eksegetiese gewig van die argument dat 1:26-27 beperk is tot tempelprostitusie en dus irrelevant is vir die hedendaagse debat, is derhalwe gering.

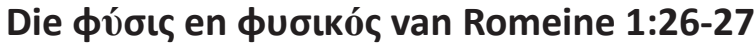 verwys na Joodse gebruike en reinheidspraktyke}

Malick (1993:329) verwys na die standpunt van sommige

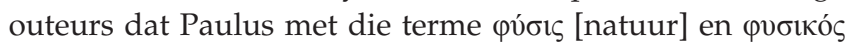
[natuurlik] in 1:26-27 sou verwys na opvattings oor homoseksuele dade wat tipies was van die destydse Joodse kultuur en dat hy dit dan sou afdwing op sy gehoor. Volgens hierdie argument kan 1:26-27 nie in die huidige debat gebruik word nie omdat spesifieke kulturele gebruike, opvattings en vooroordele van een groep nie as normatief vir almal kan geld nie. ${ }^{11}$

Verwant aan hierdie argument, maar net meer toegespits, is die siening van Countryman (1988:117) dat, hoewel Paulus homoseksuele dade as sulks in 1:26-27 afwys, moet ons dit beoordeel teen sy Joodse agtergrond wat die lewe in rein en onrein terreine verdeel het. As Jood sou hy uiteraard enige homoseksuele praktyk as tipies heidens en vir die Jood as onrein en verbode veroordeel het, ${ }^{12}$ maar dit beteken nie dat hy dit daarom as wesenlik sondig en teen die wil van God beskou nie. Hierdie siening lê ongeveer op dieselfde vlak as Paulus se argument oor sekere kossoorte wat wel vir die Jode onrein was, maar nie vir die heidene nie (Rom 14; vgl. ook 1 Kor 8). In Romeine 14 sê Paulus dat die rein/onrein-diskussie 'n middelmatige saak is waaroor Joodse Christene (die 'swakkes') en heiden-Christene (die 'sterkes') mekaar moet verdra en nie veroordeel nie. Dieselfde met homoseksuele dade: vir die Jode is dit verwerplik, maar nie vir die heidene nie. Dit lê op die vlak van wat jy vanuit jou kulturele agtergrond as rein en onrein beskou, maar dit beteken nie dat dit as sodanig 'n sondige praktyk is nie.

Eksegeties stuit bogenoemde sienings egter teen die volgende besware (vgl. Malick 1993:330-332):

- Dit is waar dat die Joodse kultuur homoseksuele dade afgewys het (vgl. Loader 2014:1-2), maar dit beteken nie dat Paulus oningelig was oor die Grieks-Romeinse wêreld en sienings op sy gehoor sou afdwing wat hulle as tipies Joodse kulturele vooroordele sou ervaar nie. Inteendeel, as boorling van die Griekse kultuurstad, Tarsus in Silisië, Klein-Asië, was Paulus goed bekend met die filosofiese strominge en literêre tradisies van sy dag (Bornkamm 1986:9). ${ }^{13}$ Dit is ondenkbaar dat Paulus nie bekend sou

11.Brownson (2013:235-237) verkies om 'natuur' op die destydse algemene sosiale konvensies van Jode sowel as Grieke te betrek - konvensies oor die onderskeie rolle van mans en vroue in die samelewing. Homoseksuele dade tussen mans sou veral die opvattings oor die hiërargie in die samelewing waar mans gedomineer het in gevaar stel deurdat hulle in 'n posisie ingedwing word om die ondergeskikte ro van die vrou te vervul.

12.Wilckens (1980:110) sê die spontane en vanselfsprekende manier waarop Paulus in 1:26-27 homoseksuele dade as tiperend van die heidene se sedeloosheid voorhou, is opvallend. Hierin is hy afhanklik van die Joodse tradisie se afkeer aan 'n Griekse lewenswyse, wat sy oorsprong het in die eeue-oue stryd onder die Jode tussen hulle wat die Griekse kultuur omarm het en dié wat dit teengestaan het.

13.Populêr Stoïsynse konsepte soos vryheid, rede, natuur, gewete, deug en plig kom vrylik by Paulus voor. Hy maak ook dikwels gebruik van Griekse retories-literêre tegnieke soos die diatribe. Tog is dit opmerklik dat daar min direkte aanhalings van Griekse wysgere of digters in sy egte briewe voorkom. Ons weet eintlik net van 
gewees het met die moraal-filosowe se oorwegend negatiewe standpunte oor homoseksuele praktyke nie. Verre sy dit dus daarvan dat Paulus tipiese eng Joodse standpunte oor homoseksuele dade op sy gehoor ${ }^{14}$ sou afdwing. Hy is juis besig om hulle 'op sy hand te kry' en sou daarom nie van argumente gebruik maak waarmee hulle nie sou saamstem nie.

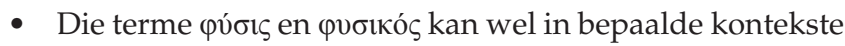
na kulturele gebruike verwys (bv. 2:27), maar die manier waarop Paulus dit in 1:26-27 gebruik, is kennelik 'n verwysing na die skeppingsorde soos deur God daargestel (kyk ook in 1 Kor 11:14 en Rom 11:21; vgl. Cranfield 1975:125; Jewett 2007:177; Schreiner 1998:95 ${ }^{15}$ en talle ander geleerdes). Die begrippe wat vir vrou en man in 1:26-27 gebruik word, naamlik $\theta \tilde{\eta} \lambda \nu \varsigma$ [vrou(lik)] en ö $\rho \sigma \eta v$ [man(lik)] in plaas van die gebruiklike $\gamma v v \eta ́$ en $\dot{\alpha} v \eta \dot{\rho}$, beklemtoon eweneens die voortplantingsrolle wat die onderskeie geslagte tydens die skeppingsgebeure ontvang. Paulus gebruik waarskynlik doelbewus hierdie terme om die assosiasie met die skeppingsverhaal te vestig, aangesien dieselfde terme in Genesis 1:27 (Septuagint - LXX) gebruik word (Debel 2009:633).

- Die opbou van die argument in Romeine 1-3 is sodanig dat Paulus eers in 2:17 die Jode pertinent aanspreek (weliswaar reeds in 2:1 geïmpliseer; vgl. Ridderbos 1959:51; Schmidt 1966:42). In Romeine 1 is hy nog besig om 'n argument te voer oor die 'natuurlike mens' op die basis van die 'algemene openbaring' en vanuit die gesigspunt van die skeppingsordeninge. Dit sou dus vreemd wees as Paulus reeds in 1:26-27 met argumente vorendag kom wat spesifieke Joodse gebruike en sentimente verteenwoordig.

- Daar is geen teksaanduiding dat Paulus in Romeine 1 oor tipies Joodse reinheidskwessies handel, soos later in Romeine 14 nie.

Die enigste slotsom waartoe mens kan kom, is dat daar geen eksegetiese basis is vir die argument dat Paulus in 1:26-27 oor tipiese Joods-kulturele vooroordele handel wat nie meer vir vandag geld nie en dat hierdie teks daarom geen rol kan speel in hierdie debat nie.

Die volgende drie pro-selfdegeslagverhoudingsargumente is met mekaar verweef, maar dit word nogtans afsonderlik in hierdie artikel hanteer om so die spesifieke beklemtoning van elkeen te belig.

\section{Heteroseksuele mense wat homoseksuele dade pleeg}

Nolland (2000:32) noem John Boswell (1980) die founding father van die standpunt dat 1:26-27 verwys na persone met

(footnote 13 continues...)

Menander in 1 Korintiërs 15:33. Verder rapporteer Lukas dat hy Aratus aangehaal het (Hand 17:28) en volgens Titus 1:12 verwys hy na Epimenides (vgl. McDonald \& Porter 2000:329)

14.Vroeër in die artikel is gemeld dat Paulus se gehoor in die Romeinebrief waarskynlik uit 'n sterk heiden-Christelike komponent - moontlik in die meerderheid - bestaan het.

15.Jewett (2007:177) kombineer Joodse opvattings en Goddelike ordeninge deur te sê dat Paulus sy Joodse opvattings probleemloos aanbied as gelyk aan Goddelike ordeninge. 'n heteroseksuele oriëntasie wat homoseksuele dade uitvoer. Die implikasie van hierdie interpretasie is dat 1:26-27 geen relevansie vir vandag se debat het nie, want dit gaan hierin juis oor mense met ' $n$ kernhomoseksuele oriëntasie wat in hierdie verhoudings betrokke is. Die basis van Boswell se argument staan op twee bene (Boswell 1980:109-110; Hays 1986:195): eerstens, die homoseksuele dade van 1:26-27 word deur heteroseksuele uitgevoer; en tweedens, die homoseksuele dade hier ter sprake is nie immoreel op sigself nie, maar eerder buite die normale. Daar word vervolgens kortliks oor elkeen gehandel:

1. Die rede waarom Boswell (1980:112-113) beweer dat dit hier oor heteroseksuele persone gaan wat homoseksuele dade uitvoer, is sy interpretasie van die werkwoorde $\mu \varepsilon \tau \eta \dot{\lambda} \lambda \lambda \alpha \xi \alpha v$ [het verander] en $\alpha \dot{\varphi} \varepsilon \dot{v} \tau \varepsilon \varsigma$ [laat vaar]: Hulle vroue het die natuurlike omgang in 'n teen-natuurlike omgang verander, en die mans het die natuurlike omgang met vroue laat vaar. Hieruit lei hy af dat dit mense is wat van nature heteroseksueel is wat teen hulle natuur in hulle seksuele oriëntasie verander of laat vaar ten gunste van homoseksuele aktiwiteite. ${ }^{16}$

2. Boswell (1980:111-112) argumenteer verder dat in die meerderheid van gevalle $\pi \alpha \rho \alpha ́$ met die akkusatief nie 'teen' beteken nie, maar 'buitengewoon' of 'buite die normale of gewone'. Wat ons dus in 1:26-27 aantref, is gedrag wat nie noodwendig immoreel is nie, maar waar mense bloot buite hulle normale aard optree. Hier verwys dit dan na mense wat buite hulle natuurlike aard as heteroseksuele by homoseksuele aktiwiteite betrokke raak.

Dit kan nie ontken word dat hierdie interpretasie wel 'n eksegetiese basis het nie - beide as interpretasie van die teks self en ook as 'n mens die destydse Grieks-Romeinse wêreld in berekening bring wat bekend was daarvoor dat heteroseksuele by homoseksuele praktyke betrokke was (onder andere by die simposia en openbare baddens). Tog word die mening gehuldig dat hierdie interpretasie deur die volgende oorwegings beklem word:

- Wat die argument van $\pi \alpha \rho \alpha ́$ met die akkusatief as 'buite (die gewone)' betref, wys Hays (1986:197-199) daarop dat daar wel 'n paar klinkklare gevalle is waar $\pi \alpha \rho \alpha$ 'téén' beteken soos in Handelinge 18:13 en Romeine 16:17. Die punt is egter dat dit nie $\pi \alpha \rho \alpha$ met die akkusatief is wat op sigself 'n 'teen'-betekenis het nie, maar die konteks wat


nie as sodanig 'n immorele betekenis nie (soos 11:24 aantoon, waar dit gewoon die neutrale betekenis van 'kunsmatig' het), maar in 1:26-27 is dit presies die konteks wat die betekenis as 'teennatuurlik' uitwys en dit die negatiewe konnotasie van 'immoreel' gee.

16.Du Toit (2007:169) voer ook dieselfde argument aan waarom hy sy standpunt sedert' $n$ vorige bydrae verander het. Voorheen het hy (Du Toit 2003) die standpunt gehuldig dat die veroordeling van homoseksuele dade in 1:26-27 konstitusionele homoseksuele insluit. Nou is hy (Du Toit 2007:168-169) egter van mening dat'n mens veel versigtiger moet formuleer. Dit gaan immers hier oor mense wat hulle mens veel versigtiger moet formuleer. Dit gaan immers hier oor mense wat hulle natuurlike orientasie verander of laat vaar om by homoseksuele praktyke betrokke te wees. Dit wil dus voorkom of Du Toit ten minste op hierdie punt saaklik by Boswell se argument aansluit, hoewel hy nie na hom verwys nie. Du Toit (2003:102 03) verwys wel in sy vorige bydrae na hom waar hy sê dat Boswell te veel in die woorde verander of laat vaar inlees. Dit dien ook hier vermeld te word dat die huidige bydraer insgelyks tans 'n ruimer standpunt huldig ten opsigte van kernhomoseksualiteit as wat in ' $n$ vorige bydrae gestel is (Van Zyl 2002:249-258). 
- Die vraag of die kwessie van seksuele oriëntasie eksegeties hier voorkom, is van kritiese belang. Dit sou Boswell se interpretasie baie gehelp het as daar in 1:26-27 gestaan het dat die vroue hulle natuurlike omgang verander het vir die teen-natuurlike, en die mans hulle natuurlike omgang met die vrou verlaat het vir dié met ander mans. Dit sou dan onteenseglik gedui het op hulle heteroseksuele oriëntasie wat genegeer word vir iets anders. Die 'hulle' staan egter nie daar nie. 'n Afleiding oor die seksuele oriëntasie van die vroue en mans soos dit in 1:26-27 voorkom, kan dus nie as 'n dwingende eksegetiese opsie gestel word nie. Hays (1986:200-201; vgl. ook Hays 1996:388-389; Loader 2014:6) opper verder 'n baie geldige beswaar as hy sê dat wat Boswell hier doen 'n klassieke voorbeeld van 'eisegese' is en nie eksegese nie, en van 'n verwarring tussen eksegese en hermeneutiek. Volgens Hays gaan dit in Romeine 1 nie oor individuele heidene met 'n bepaalde seksuele oriëntasie wie se lewenspad hulle by die punt uitgebring het waar hulle hul normale oriëntasie verlaat het ten gunste van iets anders nie. Paulus het nie individuele heidene in gedagte nie. Sy oogmerk is om die greep waarin die menslike geslag as geheel verkeer met breë kwasstrepe te skilder. In hierdie argument soos reeds hierbo verduidelik, maak hy gebruik van die begrip verander - hoe die mens die verhouding met die lewende God inruil vir of verander in die aanbidding van afgode. Al wat die sondelyste in Romeine 1 doen, is om hierdie inversie te konkretiseer - spesifiek die inversie en pervertering van die skeppingsordening rakende manlike en vroulike verhoudings. Om in hierdie argument die gedagte van seksuele oriëntasie in te bring, is ' $n$ anachronisme. Paulus spreek hom eenvoudig nie daaroor uit nie. Dit is nie in sy visier nie, dit kón ook nie wees nie (Du Toit 2007:168-169). Hoewel mens nie moet dink dat Paulus onkundig was oor die spektrum van homoseksuele praktyke wat voorgekom het nie, kan ons eenvoudig nie aanvaar dat dit Paulus se bedoeling was om hom oor iets soos seksuele oriëntasie uit te laat nie. Dit sal die invoer van 'n kategorie van denke wees wat nie deel van Paulus of sy tydgenote se verwysingsraamwerk was nie. Paulus bedoel om alle homoseksuele dade - ongeag of dit deur hetero- of homoseksuele gepleeg word - te veroordeel as teennatuurlik; as teen God se oorspronklike skeppingsbedoeling. Eksegeties is dít wat die teks sê, en daarby moet ons dit (vir eers) laat. Die hermeneutiese kwessies - soos seksuele oriëntasie wat' $n$ tipiese eietydse konsep is - kan eers as ' $n$ tweede beweging aan die orde gestel word nadat ons die teks sy woord laat spreek het.

Persoonlik is ek geneig om Hays se beswaar teen Boswell se interpretasie eksegetiese voorrang te laat geniet. 'n Mens moet egter baie goed onderskei waarop dit aankom wanneer Boswell se argument afgewys word. Uit wat ons weet vanuit die antieke wêreld kan dit nie ontken word dat homoseksuele praktyke beoefen deur heteroseksuele, wyd voorgekom het nie (kyk volgende twee afdelings). Dit is dus inderdaad moontlik dat hierdie kategorie ingesluit kan word in 1:26-27.
Wat ons eksegeties egter net nie met alle sekerheid kan sê nieen daar is Hays reg - is dat Paulus die bedoeling ${ }^{17}$ gehad het om iets soos seksuele oriëntasie, al is dit op 'n 'primitiewe', voorwetenskaplike wyse, hier aan die orde te stel. Dit sou inderdaad op 'n terreinoorskreiding tussen eksegese en hermeneutiek neerkom. Hierdie kwessie sal egter weer in die hermeneutiese besinning aan die bod kom, maar dan ietwat vanuit 'n ander perspektief. Dat homoseksuele dade gepleeg deur heteroseksuele egter inderdaad 'n eksegetiese moontlikheid is, moet aanvaar word.

\section{Pederastie}

Uit die vorige afdeling kom die vraag spontaan na vore: Van watter heteroseksuele praat ons wat betrokke kon wees by homoseksuele dade? In die moderne konteks is hierdie verskynsel bekend in die omgewing van tronke of militêre barakke waar veral mans vir lang tye in mekaar se teenwoordigheid saamgehok word. Wat is die opsies egter in die antieke konteks? Hierdie afdeling gee 'n gedeeltelike antwoord daarop. Terselfdertyd dien dit vir sommige as argument waarom 1:26-27 nie relevant vir die debat vandag sou wees nie.

Dit was veral Scroggs (1983) wat die aandag gevestig het op pederastie as moontlike agtergrond vir die homoseksuele dade van 1:26-27. Malick (1993:336) noem pederastie 'n variant van die breër kategorie van heteroseksuele persone betrokke by homoseksuele dade. Die woord pederastie beteken letterlik 'liefhebber of minnaar van seuns' (opgemaak

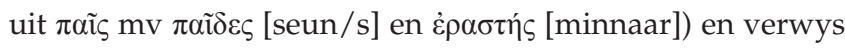
na die wydverbreide verskynsel in die antieke GrieksRomeinse wêreld waar volwasse mans dikwels 'n seksuele verhouding met seuns van gewoonlik tussen 12 en 18 jaar oud aangeknoop het. Vandag sou dit as 'n vorm van pedofilie bekend staan, strafbaar voor die reg, maar in die antieke tyd was dit nie net geduld nie, maar was daar ook in sekere kringe ' $n$ bepaalde status aan verbonde. Slawe-eienaars het soms slaweseuns op hierdie wyse misbruik, ${ }^{18}$ en generaals het dikwels vir hulle seksuele plesier 'n seun op militêre veldtogte saamgeneem. Mans het soms benewens die feit dat hulle 'n normale huweliksverhouding gehad het, ook plesierknape aangehou of besoek. Hoewel pederastie in die meeste gevalle ' $n$ ongelyke verhouding ${ }^{19}$ verteenwoordig het tussen 'n ouer man en 'n jong seun, was dit in baie gevalle nie teen die wil van die seun nie en het dit ook bepaalde voordele vir die seun ingehou soos geskenke, onderhoud en selfs

\footnotetext{
17.Ek is bewus daarvan dat outeursbedoeling'n ietwat uitgediende en gediskrediteerde

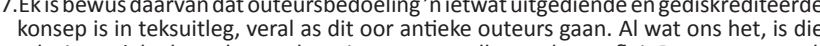
teks-in-antieke-konteks, en daaruit moet ons alles probeer aflei. Dus, wanneer ek praat van 'bedoeling', is dit net ' $n$ ander manier om te sê: dit wat ons uit die teks kan aflei teen die agtergrond van wat ons reken moontlik is vanuit die antieke konteks.

18.In die Griekse wêreld was daar nie groot diskresie uitgeoefen oor met wie 'n pederastiese verhouding aangeknoop is nie, maar by die Romeine is dit normaalweg beperk tot slaweseuns; daar was wette teen pederastie tussen ' $n$ man en ' $n$ vrygebore seun (Jewett 2007:181; Smith 1996:233).

19. Hierdie ongelykheid verklaar gedeeltelik waarom pederastie in die antieke meer aanvaarbaar was as homoseksuele verhoudings tussen volwasse mans. Phipps (2002:130) wys daarop dat seksuele penetrasie van ' $n$ volwasse man deur' $n$ ander volwasse man as teen-natuurlik en skandelik beskou is omdat die gepenetreerde volwasse man as teen-natuurlik en skandelik beskou is omdat die gepenetreerde
dan eintlik die rol van die onderdanige vrou inneem wat as besonder vernederend vir'n man beskou is.
} 
onderrig (Scroggs 1983:27-29, 34-35; Smith 1996:227-232). Ons kan aanvaar dat die voorkoms van pederastie sedert klassieke tye bekend was (vgl. Smith 1996), maar dis eweneens bekend in die Nuwe-Testamentiese era (vgl. Miller $^{20}$ 1997:861-863). 'n Mens kan dus aanvaar dat Paulus goed ingelig was oor die verskynsel van pederastie. Dit moet ook genoem word dat hoewel homoseksuele verhoudings tussen volwasse mans voorgekom het, die gevestigde patroon eerder dié van pederastie was (kyk Miller 1997:864). Vandag is dit presies andersom. Die agtergrond vir die voorkoms van en selfs 'gewildheid' van pederastie moet waarskynlik in veral die Griekse bewondering van die seunsliggaam gevind word. In die antieke was dit nie die vroulike liggaam wat as norm van skoonheid gedien het nie, maar die seunsliggaam. Die vrou is eerder gesien as ' $n$ defekte man..$^{21}$

Die redes waarom spesifiek pederastie as agtergrond vir 1:2627 aanvaar moet word, kan daarom volgens Miller (1997:863) soos volg geartikuleer word:

- Wat in 1:27 veroordeel word, is 'n bekende en aanvaarde heidense praktyk van homo-erotiek. Pederastie sou dus onmiddellik voorop in die lesers van 1:27 se gedagtes gewees het. Homoseksuele dade tussen volwasse mans was nie die norm nie. Indien Paulus na laasgenoemde wou verwys, sou hy dit spesifiek genoem het.

- Joodse bronne het dikwels homoseksuele dade veroordeel, en wanneer hulle dit gedoen het, het hulle pederastie by die naam genoem. Die term wat hulle gewoonlik gebruik het om na die mans betrokke te

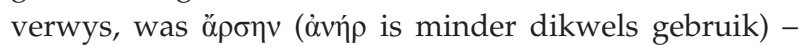
presies die term wat in 1:27 voorkom. Die terminologie is dus dié van pederastie, sonder dat laasgenoemde spesifiek genoem word.

Indien pederastie as verwysing in 1:27 aanvaar word, kan hierdie teks nie in die huidige debat gebruik word nie, want dit gaan nie oor 'ongelyke' verhoudings in hierdie debat nie, maar oor selfdegeslagverhoudings tussen gelyke partye. Daarby handel dit oor kernhomoseksuele en nie oor heteroseksuele wat by homoseksuele praktyke betrokke is nie.

Daar is egter gewigtige besware in te bring teen pederastie in die interpretasie van 1:26-27:

- Een van die belangrikste besware is sekerlik die vraag: Waarom verwys Paulus in 1:26 spesifiek na vroulike homoseksuele dade as hy pederastie (wat per definisie dade tussen mans en seuns was) in gedagte gehad het (Malick 1993:339)? Homo-erotiese verhoudings tussen

20.Miller (1997:861) kritiseer Smith (1996) juis omdat laasgenoemde nie voldoende bronne uit die Nuwe-Testamentiese era gebruik om die wye voorkoms van pederastie in hierdie tyd te beredeneer nie. Miller verskaf vervolgens genoegsame getuienis hiervan.

21.Vir ' $n$ goeie oorsig oor die dominerende diskoers in die antieke van die manlike fallus, die siening oor die seunsliggaam en dié van die vrou, sowel as ' $n$ bespreking van vard word, sien Vorster nie enige verband tussen 1:26-27 en vandag se debat nie. Volgens hom (Vorster 2006:451-452) gebruik Paulus in Romeine 1 'n vorm van vilifikasie om die heidene as 'n buitegroep voor te stel. vroue in die antieke is wel bekend, maar daar is nie 'n parallel vir pederastie onder vroue nie. Vanuit die beskikbare gegewens is die meeste wat ons kan sê dat homoseksuele verhoudings tussen vroue dié van volwasse, toestemmende partye was (Smith 1996:243). Dit is verder ook nie seker of 1:26 wel na homo-erotiek tussen vroue verwys nie. Daar word immers nie pertinent verwys na verhoudings tussen vroue soos 1:27 na verhoudings tussen mans verwys nie. Dit is slegs by

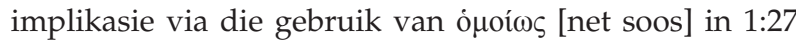
waar eksplisiet van homoseksuele dade tussen mans gepraat word dat die afleiding 'terugwaarts' gemaak word dat 1:26 se teen-natuurlike dade van vroue ook na vroulike homoseksuele praktyke verwys. Banister


Testament ondersoek en wys daarop dat in bykans $90 \%$ van die gevalle dit onmoontlik of onlogies is om die

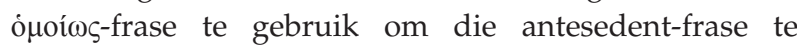
interpreteer. Daar is dus die moontlikheid dat wat ná die

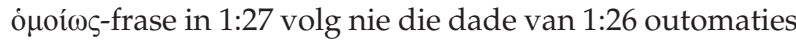
tot homo-erotiese dade tussen vroue beperk nie. Dit is baie moontlik dat Paulus na ander vorme van vroue se teen-natuurlike dade verwys, soos anale of orale seks in heteroseksuele verhoudings wat moontlik ten doel gehad het om bevrugting te vermy (kyk Miller 1995:10; Debel 2009:638-640). Op grond van die parallel tussen 1:26 en 27 is die mees voor die hand liggende interpretasie egter dat daar ook in vers 26 na vroulike homoseksuele dade verwys word. Soos reeds genoem, vroulike homo-erotiek was bekend genoeg in die antieke dat Paulus kon aanvaar sy lesers sou weet waarna hy verwys (vgl. Du Toit 2003:99). Hoewel dit dan die enigste plek in die Nuwe Testament sal wees waar na vroulike homoseksuele dade verwys word, bly dit die beste keuse. Hoe ook al, die verwysing na vroue in 1:26 - of dit nou homoseksueel of heteroseksueel verstaan word - maak 'n pederastiese interpretasie van 1:26-27 hoogs onwaarskynlik. Paulus redeneer omvattend en daarom betrek hy ook teennatuurlike homoseksuele dade onder vroue om die totale verwording onder die heidene voor te stel.

- Hoewel pederastie wyd voorgekom het in die antieke ook in Paulus se tyd - was dit nie die enigste of selfs dominante vorm van homoseksuele dade nie (Kuhn 2006:315). Daar is genoeg bewyse van ander vorme van homoseksuele dade, selfs tussen vroue soos in die vorige punt genoem (vgl. die getuienis wat Smith 1996:234-244 in hierdie verband versamel het). Dit is dus moeilik om te aanvaar dat pederastie die voor-die-hand-liggende model van homoseksuele dade sou wees wat by Paulus en sy lesers sou opgekom het.

- Die taalgebruik in 1:27 hoef nie net na pederastie te verwys nie, maar is van 'n meer algemene aard. Die verwysing na mans wat in begeerte brand 'vir mekaar'

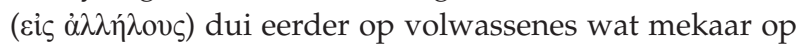
gelyke vlak begeer as die tipies pederastiese ongelyke verhouding waar mans seuns aanhou of besoek - 'n situasie wat nie noodwendig resiprositeit inhou nie (Kuhn 2006:315-316; Malick 1993:339). Daarby is die term 


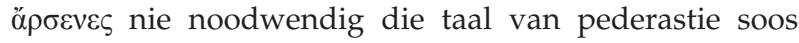
Miller (1997:863) dit wil hê nie, maar eerder 'n verwysing na die woorde van Genesis 1:27 (LXX) en probeer Paulus so 'n doelbewuste band lê met die skeppingsverhaal (Du Toit 2003:101).

- Die vraag kan ook gevra word waarom Paulus pederastie nie by die naam noem as dít die agtergrond is wat hy in gedagte het nie. Die antwoord hierop is gewoon omdat Paulus nie spesifieke afwykende vorms van homoseksuele praktyke in gedagte gehad het nie, maar in universele terme in Romeine 1 argumenteer. Hy veroordeel homoseksuele dade as sodanig, of dit nou gepleeg word deur homo- of heteroseksuele volwassenes of minderjariges (Du Toit 2003:103).

Ons slotsom is dus dat hoewel pederastie wyd voorgekom het in die antieke en nie noodwendig uitgesluit is in Romeine 1:26-27 nie, daar nie genoegsame eksegetiese getuienis is dat dit die uitsluitlike vorm van homoseksualiteit is wat Paulus hier in gedagte het nie. Dit sou teen die algemene trant van sy beredenering ingaan.

\section{Romeine 1:26-27 handel oor 'n ekstreme, wellustige vorm van seks}

Waar die vorige interpretasie ' $n$ poging was om die identiteit van die heteroseksuele wat by homoseksuele dade betrokke is te presiseer (mans wat by pederastie betrokke is), probeer die onderhawige een die aard daarvan peil. Watter soort homoseksuele gedrag deur (veral) heteroseksuele, is ter sprake?

Daar is verskeie navorsers wat daarop wys dat die aard van die homoseksuele gedrag wat deur Paulus in 1:26-27 veroordeel word op 'n besonder uitspattige of wellustige vorm van seks dui. Steyn (2007:198-200) sê dit is opmerklik hoe die beskrywing van homoseksuele dade in 1:26-27 in die konteks van negatiewe, onbeheerste seksuele drange geplaas word. Debel (2009:637) noem dat homoseksuele dade in die Griekse en Romeinse geskrifte van Paulus se tyd nie soseer gesien is as dié van mense met 'n inherente drang na selfdegeslagseks nie, maar eerder as die manifestasie van 'n onversadigbare wellus. Hultgren (1994:319-320) sê dat die

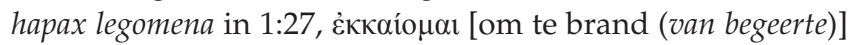
en ő $\rho \xi \xi \varsigma$ [wellustige begeerte], dikwels in die Joodshellenistiese literatuur voorkom as aanduiding van seksuele drange en praktyke wat die normale ver te bowe gaan. Kuhn (2006:316-317) verwys na David Fredrickson wat via die woord $\chi \rho \tilde{\eta} \sigma ı \varsigma$ [gebruik (seksuele omgang)] in 1:26-27 klem daarop lê dat dit hier nie oor normale seksuele omgang gaan nie, maar oor mense wat ander net as seksobjekte gebruik om hulle eie onversadigbare seksdrange mee te bevredig. Ward (1997:284; vgl. ook Loader 2014:1-3) wys vervolgens daarop dat die 'teennatuurlik' argument van Paulus waarskynlik die anti-hedonistiese tendense van die Joodshellenistiese literatuur in die algemeen, maar veral van Filo van Aleksandrië ten grondslag lê. Volgens hierdie tendense was enige vorm van seks wat nie afgestem was op die skeppingsopdrag van voortplanting nie, tiperend van teen-natuurlike seksuele oordaad en hedonisme. In hierdie konteks is homoseksuele dade dus by verstek altyd in verband gebring met mense wat voortdurend op soek was na nuwe en aweregse seksuele avonture, na ekstreme vorme van seksuele uitlewing. Die normale en natuurlike is om seks binne die sosiale struktuur van die huwelik - soos deur God daargestel - en met die oog op die uitbou van die menslike geslag te beoefen. Vir baie was dít egter nie genoeg nie - vandaar die betrokkenheid by eksotiese seksuele praktyke wat net afgestem was op egoïstiese selfbevrediging en selfgelding (vgl. ook Dozeman 1995:178). In hierdie verband wys Brownson (2013:149-178) op die konteks van wellus en begeerte waarin die homoseksuele dade van die heidene in 1:26-27 beskryf word. In 1:24 word gepraat van die 'drange van hulle hart' en 'sedelike onreinheid' waaraan God hulle oorgee sodat hulle 'hulle liggame onder mekaar onteer'. Dit gaan oor 'skandelike drifte' (1:26) en "n brand van begeerte vir mekaar', oor die doen van 'skandelikhede' en 'perversiteit' (1:27). Volgens Brownson is dit moeilik om hierdie beskrywing in verband te bring met die moderne konsep van homoseksuele oriëntasie waar mense nie 'n natuurlike aangetrokkenheid het na die teenoorgestelde geslag nie, maar na dieselfde geslag. Hierdie perspektief word nêrens in die literatuur van Paulus se tyd gevind nie. Inteendeel, wanneer homoseksuele dade beskryf word, is dit volgens Brownson (2013) altyd:

as a particular manifestation of self-centered lust, one that is not content with women alone but is driven to ever more exotic and unnatural forms of stimulation in the pursuit of pleasure. (p. 156)

Selfgesentreerde wellus manifesteer egter nie net op seksuele gebied nie, maar is volgens Brownson (2013:161-163) ingebed in die teologiese argument van Romeine. Trouens, dit vorm die kern van Paulus se betoog. Hy sien nie net die heidene as slagoffers van menslike hubris nie, maar ook homself en sy mede-Jode. Sélf het hulle 'n sisteem van eiegeregtigheid probeer opbou waarmee hulle God wou beïndruk. Dieselfde

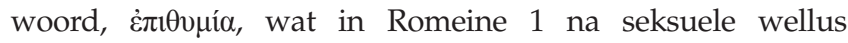
verwys, kry in 7:7-10 (saam met die werkwoord غ̇лı $\theta u \mu \varepsilon \dot{\varepsilon} \omega$ ) 'n teologiese konnotasie wanneer dit Paulus se begeerte na selfverwesenliking beskryf. Deur die wet wou hy na God uitstyg, maar dit het klaaglik misluk. Hy moes afstand doen van sy hubris en leer leef uit God se genade in Jesus Christus.

Die interpretasie van die homoseksuele dade in 1:26-27 as uitdrukking van seksuele wellus deur heteroseksuele, is 'n gewigtige een. Dit kom daarop neer dat dit nie soseer gaan oor die homoseksuele dade as sodanig wat veroordeeld staan nie, maar eerder oor die uitspattige hedonisme wat dit verteenwoordig en dat dít teen God se skeppingsdoel met man en vrou indruis. Vir Paulus is die teennatuurlike begeerte en handeling immers een en dieselfde saak (Kuhn 2006:318). Dit is moeilik om te ontken dat hierdie siening van homoerotiek medebepalend is vir die negatiewe beoordeling van homoseksuele dade in die antieke. Dit is ook onteenseglik in die teks van Romeine 1 teenwoordig en kan dus eksegeties nie geïgnoreer word nie. Dat dit ' $n$ rol moet speel in ons beoordeling van die debat vandag spreek vanself. Indien die 
homoseksuele dade in 1:26-27 tiperend is van oordadige, afbrekende en onterende seksualiteit waarmee veral moderne Christen-gays hulle moeilik kan vereenselwig, kom die relevansie van 1:26-27 vir die debat inderdaad in die gedrang. Tog mag ons nie uit die oog verloor nie, en 'n oorweldigende aantal navorsers wys daarop (kyk volgende hoofafdeling, 'Hermeneutiese Besinning', se inleiding), dat die verwysing na die Goddelike skeppingsordening rakende die ideale verhouding tussen man en vrou die eksegetiese ruggraat van Paulus se argument in Romeine 1 vorm. Dit is daarom nie net die seksuele perversiteit as sodanig wat afgewys word nie, maar ook die feit dat dit gekoppel is aan die gedagte van verandering en laat vaar: vroue verander die natuurlike verhouding met mans ten gunste van vroue, en mans laat vaar die natuurlike verhouding met vroue ten gunste van mans. Indien hierdie aspek nie ook 'n rol speel nie, word Paulus van sy Joodse agtergrond vervreem. Daar sal weer kortliks by hierdie skeppingsordening-argument stilgestaan word by die inleiding van die volgende hoofafdeling, 'Hermeneutiese Besinning'.

\section{Samevatting}

Uit die oorsig oor die eksegetiese argumente wat aanvoer dat 1:26-27 nie relevant is vir die moderne debat nie, het dit duidelik geblyk dat elkeen van die interpretasies 'n waarheidsmoment bevat, maar dat nie een werklik eksegeties oortuig dat 1:26-27 tot 'n bepaalde aspek van homoseksuele dade beperk moet word nie - of dit nou tot 'n blote standaardlys van bekende heidensondes is, of tot tempelprostitusie, of tot Joodse kulturele opvattings, of tot heteroseksuele wat by homoseksuele praktyke betrokke is, of tot pederastie, of tot'n perverse vorm van seks. Laasgenoemde het myns insiens wel 'n sterk eksegetiese oortuigingskrag en moet 'n rol speel in die finale beoordeling van die toepaslikheid van 1:26-27 vir die huidige debat, maar dit kan nie die enigste argument wees nie - dit moet as onderdeel by 'n breër hermeneutiese besinning ingebed word waarby ons vervolgens sal stilstaan.

\section{Hermeneutiese besinning}

Aan die begin van die artikel is genoem dat dit in die beredenering van die relevansie van 1:26-27 vir die huidige debat sin maak om eksegese en hermeneutiek as twee aparte bewegings te hanteer. Die vorige afdeling onder die opskrif 'Eksegetiese argumente' het aangedui dat nie een van die sogenaamde pro-selfdegeslagverhoudingsargumente oor die eksegetiese 'slaankrag' beskik om 1:26-27 se relevansie uit te skakel nie. Die meerderheid eksegete wys daarop dat Paulus in Romeine 1 as eksponent van sy Joods-hellenistiese agtergrond gewoon aanvaar dat homoseksuele dade nie in ooreenstemming is met die Goddelike skeppingsordeninge rakende man en vrou nie. Die vernaamste argumente ten gunste van hierdie standpunt kan kortliks soos volg saamgevat word: $:^{22}$

22. Hierdie argumente word deur die volgende eksegete ondersteun: Botha en Janse van Rensburg (2004:43); Dozeman (1995:170-178); Dunn (1988:74); Fitzmyer (1993:270); Hays (1996:387); Loader (2014:4); Moo (1996:115); Nolland (2000:52), Schreiner (1998:95).

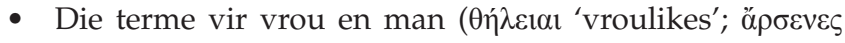
'manlikes') verwys doelbewus na die skeppingsverhaal soos in Genesis 1:27 (LXX), waar dieselfde terme voorkom (daar egter in omgekeerde volgorde: eers man, dan vrou). Die feit dat hulle in samehang met púoıs ['natuur'] gebruik word, laat die voor-die-hand-liggende bedoeling van God met die skepping van manlikes en vroulikes na vore tree, naamlik voortplanting. Enige seksuele handeling wat hierdie bedoeling probeer fnuik, is

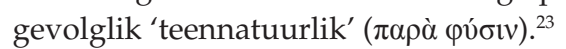

- Paulus word kennelik geïnformeer deur sy Joodshellenistiese agtergrond wat negatief teenoor alle homoseksuele dade staan. Op sy beurt is hierdie agtergrond ingebed in die priesterlike heiligheidskodeks van Levitikus 18 en 20, waar seksuele dade tussen mans uitdruklik verbied word. Laasgenoemde gaan weer terug na die skeppingsverhaal van man en vrou wat as twee teenoorstaande geslagte vir mekaar geskep is tot uitbou van die menslike geslag.

- Die verwysing na Levitikus 18:22 en 20:13 onderstreep die gedagte dat, vir die Jood in die algemeen en vir Paulus in die besonder, die natuur nie die deurslaggewende argument is nie, maar die Tora. Die probleem met homoseksuele dade is nie in die eerste plek dat dit die natuur vertroebel nie, maar dat dit teen die wil van God is. Paulus sien die natuur in die lig van die Goddelike openbaring, nie andersom nie.

- Die taal van inversie (verandering) wat 1:18-32 onderlê (mense wat God verruil vir afgode, die waarheid vir die leuen, die natuurlike seksuele omgang vir die teennatuurlike) moet verstaan word teen die agtergrond van die struktuur van die skepping soos deur God daargestel. Die natuurlike word deur hierdie Godsgewilde kosmologie ondersteun, en as mense dit probeer verander in sy teendeel, blyk die mens se geneigdheid tot afgodsdiens.

Die eksegese wys dus duidelik uit wat die intensie van die teks in sy oorspronklike konteks is: Paulus wys onteenseglik homoseksuele dade soos hy dit verstaan het af as teen die wil van God. Daarmee is die gesagsvraag egter nog nie afgehandel nie. Nou begin dit eers. Die gesagsvraag handel oor die hermeneutiese teksworsteling met die oog op vandag se etiese vraagstukke - vraagstukke wat nie noodwendig in die eerste eeu op die tafel was of presies só ter sprake was nie. In die hoofafdeling 'Onderskeid tussen Eksegese en Hermeneutiek' is reeds teoreties hieroor gehandel; nou wil ons dit prakties hanteer rakende 1:26-27 en die debat.

Daar is volgens navorsers 'n weg waarop met die Skrifgegewens omgegaan kan word wat aan die Skrifgesag voldoen sowel as ruimte skep vir belydende Christene met 'n kernhomoseksuele oriëntasie. Dit is 'n weg wat vir baie gelowiges miskien nuut is in sy toepassing op die debat

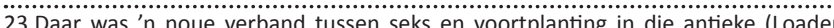
2014:2). Die moderne konsep van seks as iets wat nie lewensbelangrik is nie en wat deel is van die ontspanningsgedrag van mense van gelyke status, het nie in die antieke bestaan nie. Die samelewing was hiërargies gestruktureer en seksuele antieke bestaan nie. Die samelewing was hiërargies gestruktureer en seksuele
gedrag is primêr bepaal deur sosiale verantwoordelikhede en konvensies - soos deur die man bepaal, en nie deur persoonlike voorkeure nie (vgl. Punt 2006:423). 
(en daarom onaanvaarbaar is), maar wat nie nuut is in die manier waarop ons met die Skrif omgaan in ander soortgelyke sake nie. Eintlik het ons dit nog altyd gedoen, maar net nog nie konsekwent toegepas op die verskynsel van kernhomoseksualiteit nie. Dit wat ons nog altyd gedoen het in Skrifverstaan, moet ons nou net konsekwent uitvoer en nie soos dit ons pas nie. ${ }^{24}$ Ons is na alles op soekna'n konsekwente hermeneutiek.

Daar is veral twee argumente wat in die literatuur ter sprake kom in 'n hermeneutiek wat positief staan teenoor selfdegeslagverhoudings.

\section{Wetenskaplike getuienis omtrent kernhomoseksualiteit}

Dit was nog altyd so dat duidelike Skrifuitsprake in die lig van nuwe wetenskaplike getuienis in gedrang kom. Die verantwoordelike Christen kan immers nie skisofrenies in twee botsende wêrelde leef nie. Met die ontdekkings van 'n heliosentriese sonnestelsel, evolusie en paleontologiese bewyse vir die hoë ouderdom van die kosmos en die aarde, was die kerk verplig om weer nuwe antwoorde te vind vir die 'drieverdieping'-wêreldbeeld van die Bybel en die skeppingsverhale van Genesis 1 en 2. Dit het lank geneem om te besef dat die Bybel nie 'n natuurwetenskaplike bron is wat alternatiewe, gesagvolle natuurwetenskaplike inligting oor die skepping bied nie. Die gesag van die Bybel lê in 'n ander rigting, te wete die perspektief wat dit op die karakter van God en die mens, God se handelinge met sy skepping en die verhouding tussen God en mens open.

Wat ons onderwerp betref, het daar insgelyks veral die afgelope vier dekades nuwe wetenskaplike inligting na vore gekom wat die kerk verplig om die Skrifuitsprake wat oënskynlik oor homoseksualiteit handel, opnuut in oënskou te neem. (In die vorige hoofafdeling het ons juis probeer aantoon hoe eksegete in die lig van hierdie nuwe inligting probeer om die relevansie van 1:26-27 vir vandag se debat te minimaliseer.) Die nuwe inligting wat gaandeweg sy weg na die openbare domein gevind het, is die erkenning van die verskynsel van kernhomoseksualiteit. Daar word bereken dat ten minste $1.5 \%$ van mans en $1.0 \%$ van vroue in enige bevolking as kernhomoseksueel beskou kan word. Wanneer gegewens oor bi- en transseksualiteit bygevoeg word, kan die getal mense wat nie-heteroseksueel is rofweg op 5.0\% gestel word (ASSAf 2015:37). Verder hanteer die mediese wetenskap kernhomoseksualiteit nie meer as 'n afwykende gedragsvorm nie. Reeds in 1973 het die American Psychiatric Association (APA) homoseksualiteit afgehaal van hulle diagnostiese lys van psigiatriese afwykings (vgl. Malick 1993:328). Daar is egter nog nie absolute konsensus onder wetenskaplikes omtrent die oorsake van selfdegeslagoriëntasie nie, hoewel die oorwig van getuienis daarop

24. Kalin (2003:423) wys op die inkonsekwente manier waarop byvoorbeeld gebruik gemaak word van die heiligheidskode in Levitikus 18. Daar word groot gewag

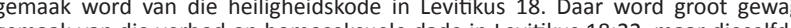
gemaak van die verbod op homoseksuele dade in Levitikus 18:22, maar dieselfde kode sê ook dat mens nie 'n kledingstuk van verskillende soorte materiaal mag dra nie (Lev 19:19). Waarom eersgenoemde letterlik toepas en nie ook laasgenoemde nie? 'n Konsekwente hermeneutiek probeer hierdie soort anomalieë vermy. begin dui dat dit vermoedelik voorgeboortelik vasgelê word.$^{25}$ Hoewel daar nog nie 'n spesifieke geen geïdentifiseer is wat homoseksualiteit veroorsaak nie, is daar 'n sterk verband gevind tussen ten minste manlike homoseksualiteit en areas op die X-chromosoom wat 'n sterk aanduiding is van ' $n$ genetiese komponent in selfdegeslagoriëntasie (ASSAf2015:39; Warnich2015) ${ }^{26}$ Verderword voorgeboortelike neuro-hormonale ontwikkeling ook as 'n sterk basis vir seksuele oriëntasie aangedui (ASSAf 2015:38-39). Hierdie bevindings word ondersteun deur sosiologiese studies dat 'n homoseksuele voorkeur nie mense se eie keuse is nie en dat dit onomkeerbaar is (ASSAf 2015:39). Wat die keuse betref: dít is die groot verskil tussen 1:26-27 en vandag se situasie rakende mense met 'n homoseksuele oriëntasie. In die afdeling 'Heteroseksuele mense wat homoseksuele dade pleeg' is betoog dat die homoseksuele dade van Romeine 1 beoefen word deur mense wat willens en wetens hierdie keuse uitoefen as manifestasie van afgodsdiens ongeag of hulle heteroseksuele is wat by homoseksuele dade betrokke is of homoseksuele wat homoseksuele dade beoefen. Kernhomoseksuele, soos vandag gedefinieer, het egter nie 'n keuse oor hulle oriëntasie en seksuele aangetrokkenheid tot dieselfde geslag nie. Trouens, indien hulle 'n keuse gehad het, sou hulle dit nie wou wees nie vanweë die verguising en verwerping wat hulle dikwels in die samelewing en familiekring ervaar. Wat die onomkeerbaarheid betref: Pogings om 'n homoseksuele oriëntasie deur middel van herstellende of bekeringsterapie te verander, is nie net onsuksesvol nie, maar lei tot verdere trauma en selfs selfmoord. ${ }^{27}$ Die gevolg is dat die APA in 2000 besluit het om by hulle lede aan te beveel dat alle sodanige terapieë gestaak word.$^{28}$ Hierby moet ook gevoeg word dat talle homoseksuele reeds in vaste verhoudings saamwoon (waarvan sommige slaag en ander verbrokkel soos ook in heteroseksuele verhoudings), dat paartjies selfs in selfdegeslaghuwelike bevestig word (in sommige state van die VSA), en dat formele burgerlike selfdegeslagverbintenisse reeds sedert 2006 in Suid-Afrika wettig is. ${ }^{29}$

Die kerk bevind hom dus toenemend in ' $n$ situasie waar hy moet besluit hoe om Christen-homoseksuele wat

25.Daar is geen direkte korrelasie tussen homoseksuele oriëntasie en omgewingsfaktore soos die verhouding tussen ouers en kinders en die manier waarop kinders grootgemaak is, gevind nie (ASSAf 2015:44).

26.Tydens ' $n$ konferensie oor selfdegeslagverhoudings by die Fakulteit Teologie van die Universiteit van Stellenbosch in November 2015, het prof Louise Warnich, genetikus van Stellenbosch, verduidelik dat anders as by iets soos sistiese fibrose verskynsel soos homoseksualiteit ' $n$ hele area in die DNS is waar gene ' $n$ rol sou kon speel.

27.Die gevalle van suksesvolle terapie is gewoonlik van mense wat nie regtig kernhomoseksueel is nie, maar wat om welke rede ook al met homoseksualiteit geëksperimenteer het en toe vasgevang is. Feit is dat diegene wat getuig dat hulle homoseksuele gedrag na heteroseksueel verander het veel minder is as diegene wat sê dat, ten spyte van talle ernstige pogings van hulle kant om hulle homoseksuele geneigdheid te verander, dit onveranderd gebly het (De Villiers 2007:286).

28. Die volledige besluit en agtergrond is beskikbaar in die volgende dokumente wat op die webblad van die APA (2000) bekombaar is.

29. Hoewel die NG Kerk in sy besluit van 2015 'n onderskeid tussen ' $n$ huwelik (slegs tussen 'n man en 'n vrou) en ' $n$ burgerlike verbintenis (tussen mense van dieselfde geslag) tref, maak die Civil Union Act (Republic of South Africa 2006) nie so 'n onderskeid nie. In die oë van die staat is ' $n$ selfdegeslagverbintenis dus vir alle praktiese en wetlike doeleindes 'n huwelik. 
verbintenisse van liefde en trou wil aangaan, ${ }^{30}$ kerklik te akkommodeer en hoe hierdie verbintenisse in die lig van die Skrif beoordeel moet word. Dat die kerk hom in ' $n$ nuwe situasie bevind wat homoseksuele betref, is onteenseglik waar. Hermeneuties gesproke is dit nie wesenlik anders as toe die kerk oor die 'hoed-kwessie' vir die vrou in die erediens of die vrou in die besondere ampte moes besluit nie. Daar is dringende eietydse omstandighede en wetenskaplike argumente wat besluitneming en optrede deur die kerk verg. Die kerk is geroepe om op 'n manier te handel wat aan die wetenskaplike eise van die dag sowel as aan die gesag van die Skrif reg laat geskied (vgl. Loader 2014:8).

\section{Skrifhantering}

Verskeie navorsers (bv. Du Toit 2007:169; Steyn 2007:199-200; Hays 1986:200) wys daarop dat die saak waaroor dit vandag gaan, naamlik kernhomoseksuele oriëntasie, eksegeties gesproke nie in Paulus se visier was toe hy 1:26-27 geskryf het nie. Hy veroordeel die sondes van die heidene waaronder homoseksuele praktyke, maar hy hanteer nie eksplisiet die kwessie van kernhomoseksualiteit nie. Hierdie saak was nie in die antieke teenwoordig op dieselfde manier waarop dit vandag onder ons aandag is nie (Hultgren 1994:322). Ons weet gevolglik nie hoe Paulus sou reageer indien hy met so 'n situasie gekonfronteer was nie. ${ }^{31}$ Dalk dieselfde as in 1:26-27, of dalk sou hy nie daarvan 'n groot kwessie gemaak het nie; daar was immers vir hom groter sondes om oor bekommerd te wees (Smith 1996:250). Dalk sou hy in die lig van 2:1 daarop gewys het dat niemand in elk geval voor God regverdig is nie. 'n Mens moet dus nie te hovaardig oordeel oor homoseksuele nie (Hays 1986:210). Hoe dit ook al sy, ons beste opsie is om in die lig van empiriese navorsing (wetenskaplike insigte) en die ervaring van suksesvolle homoseksuele verbintenisse die Skrifgegewens weer te besoek (Hays 1986:211). Dit is presies die taak van die hermeneutiek. Onderstaande beredenering sien navorsers as ' $n$ verantwoordelike Skrifhantering rakende kernhomoseksualiteit.

As uitgangspunt word aanvaar dat 'n mens hierdie aangeleentheid nie met' $n$ fundamentalistiese Skrifbenadering kan hanteer nie. Ons is nie letterknegte nie - hoewel die Bybelteks ons toegang tot God is, aanbid ons nie die teks nie. Ons is primêr deur Jesus op God gerig. Ons verwagting is dat die Heilige Gees ons in alle waarheid sal lei (Joh 16:13), ook waar ons nie 'n direkte Skrifwoord het nie (1 Kor 7:12) of waar die Skrifwoord ons kennelik nie voldoende help in 'n eietydse problematiek soos homoseksualiteit nie. Soos De Villiers (2007) dit stel:

Nuwe-Testamentiese skrywers ... lewer geen uitspraak oor die moontlikheid dat ook konstitusionele homoseksuele persone trou kan wees in vaste homoseksuele verhoudings nie. Die leser

30.Dit spreek vanself dat die kerk nie promiskue gedrag en verhoudings wil of kan goedkeur nie - nie tussen heteroseksuele of homoseksuele nie.

31.Loader (2014:6-8) gebruik die term sexual orientation om na die homoseksuele dade van 1:26-27 te verwys omdat, volgens hom, daar vir Paulus geen onderskeid 'brand van begeette na dil 'briënt van begeerte na mekaar') en ', de dade wat daaruit voortvloei nie. Hierdie orientasie is egter, volgens Loader, ' $\mathrm{n}$ perverse orientasie en nie gelyk aan wat vandag onder 'seksuele oriëntasie' verstaan word nie. Laasgenoemde is vir Loade prakties gelyk aan mense se 'natuurlike staat'. soek tevergeefs in die Bybel na 'n direkte antwoord op hierdie eietydse vraag. (bl. 286-287)

Die eksegese het duidelik aangedui dat die skeppingsordeargument deurslaggewend is in Paulus se denke oor homoseksuele dade. Dit kan egter nie die laaste woord spreek nie, want in die Skrif self is aanduidings dat die natuur nie God se finale woord is nie. Ons mag nie vasval in 'n soort natuurlike teologie nie. ${ }^{32}$ Daar is ten minste twee Skrifgedeeltes wat in hierdie verband lig werp. Die Skrif is baie duidelik oor die verbod op egskeiding en hertrou (Mark 10:2-12; 1 Kor 7:10-11). In Markus 10:9 verwys Jesus spesifiek na die oorspronklike bedoeling van God met die huwelik: wat God saamgevoeg het, mag die mens nie skei nie. Tog het Moses die volk toegelaat om weens die hardheid van hulle harte te skei. Dan mag man en vrou egter nie weer na die egskeiding trou nie omdat dit op egbreuk sou neerkom. Dit is hier waar 'n konsekwente hermeneutiek belangrik word: indien ons téén die uitdruklike bedoeling van God, soos dit uit die skepping van man en vrou blyk, tog in bepaalde gevalle toelaat dat mense skei en weer hertrou, moet daar ten minste begrip wees daarvoor dat mense met 'n kernhomoseksuele oriëntasie wat in verhoudings van liefde en trou wil leef, toegelaat word om dit te doen, al is dit teen die oorspronklike bedoeling van God (Hultgren 1994:322; Loader 2014:8). Ons leef immers nie in 'n volmaakte, ideale wêreld nie. Wat gebeur is dikwels nie hoe God dit oorspronklik bedoel het nie. Tog moet ons mense ontmoet en bedien waar hulle werklik is en daarvan die beste maak. $\mathrm{Na}$ alles is dit beter om in 'n verhouding van liefde en trou te leef as in promiskuiteit, al is dit nie God se ideale wil nie. Nog 'n voorbeeld: in die gebeure van die eunug uit Etiopië (Hand 8:26-39) beleef ons ook iets van die genade van God wat teen die natuur en die Tora ' $n$ deurbraak in die hantering van mense verteenwoordig. Volgens die wet van Moses (Deut 23:1) sou die eunug nie tydens sy besoek aan Jerusalem die tempel kon binnegaan nie weens sy verminkte natuur. Hy word egter deur Filippus gedoop en so in die nuwe volk van God, die kerk, opgeneem. Sy natuur en die Tora het teen hom getel, maar die genade van God roem teen albei en hy word volledig in die Nuwe-Testamentiese kerk van Christus opgeneem. Net so behoort Christen-homoseksuele volledig deel te wees van die gemeente van Christus, as volle mense, met al die voorregte en regte soos ander lidmate sonder enige beletsel (Brownson 2013:251). Romeine 8:21-23 praat immers van die bevryding van die skepping van sy verslawing aan die verganklikheid, en dat die natuur in geboortepyne van volkome verlossing verkeer. Daarom kan ons nie God se finale doel vir die skepping aflees uit die oorspronklike, natuurlike orde nie. Inteendeel, ons moet kyk na die visie oor die toekoms wat in die evangelie van Christus weggelê is (Brownson 2013:250). Davies (1995:324-327, 329) wys ook daarop dat Paulus self, nieteenstaande sy argument oor dit wat teennatuurlik is in 1:26-27, aantoon dat nie alle teennatuurlike gebeure negatief beoordeel moet word nie. Die

32. Suid-Afrika se apartheidsverlede behoort as waarskuwing te dien vir watter probleme mens met 'n natuurlike teologie op die lyf loop in die geval van rasseverhoudinge wat net op sogenaamde natuurlike skeppingsordeninge gebou word. 
inenting van die wilde olyftakke (die heidene) op die mak stam (Israel) (11:16-24) wys dat hierdie teen-natuurlike handeling deur die genade van God geïnisieer en gedra word. Ons moet minstens kan sê dat Paulus die argument oor die natuur dubbelsinnig gebruik en wat die verhouding tussen die geslagte betref, dryf Paulus nie die verskille tussen man en vrou op die spits nie. Nie net word hierdie verskille vanuit die verhouding in Christus gerelativeer nie (Gal 3:28: 'daar is nou geen man of vrou meer in Christus nie'), maar wanneer Paulus in sy egte briewe oor die huwelik handel, word selibaatskap bo die huwelik verkies (1 Kor 7:6-9), hoewel die huwelik self nie gering geag word nie. Voortplanting word ten minste nie meer as die hooftaak van die vrou gesien nie. Haar plek in die koninkryk van God ontvang nou die hoofklem. Paulus is dus in 1:26-27 besig met 'n baie spesifieke argument vanuit die natuur om ' $n$ bepaalde punt te bewys, terwyl hy op ander plekke nie die natuur of die geykte opvattings oor die huwelik of die vrou as deurslaggewend beskou nie (vgl. ook Dozeman 1995:185).

Verwant aan die feit dat mens jou nie net kan laat informeer deur 'n natuurlike teologie nie, is die verskynsel van voortdurende herinterpretasie wat in die Skrif self voorkom. Kuhn (2006:319-329) sluit aan by die gedagte dat ons Paulus nie in ons ywer om die pro-selfdegeslagverhoudingsargument te fasiliteer moet maak sê wat hy nie sê nie. Kuhn sê daar is ' $n$ ander weg - die een wat die Skrif self aanwys deur die Heilige Gees as die hermeneut by uitstek wat die kerk voortdurend in nuwe waarhede lei waar daar nie duidelike leiding uit Skrifgegewens self is nie. Byvoorbeeld, die Skrif is nie baie helder oor die afwysing van manlike patriargalisme en slawerny nie. Tog het die Heilige Gees oor tyd heen die kerk met nuwe oë laat kyk na die negatiewe effek van hierdie verskynsels en gemaak dat sekere tekste (bv dié wat oënskynlik slawerny perpetueer) na die agtergrond gedruk en ander wat die gelykheid van mense beklemtoon na die voorgrond gebring is. Net so moet ons fyn luister hoe God se liefdesgebod in moeilike kwessies, soos homoseksualiteit nuut beluister moet word. Selfdegeslagverhoudings wat in wedersydse liefde, trou en respek geleef word, kan ook God se wil weerspieël. Christus Self het die Skrif nuut geherinterpreteer vir sy tyd ('julle het gehoor dat gesê is, maar Ek sê vir julle ...'). So vra die Skrif voortdurende onderskeidingsvermoë en herinterpretasie in die lig van nuwe omstandighede en kennis wat nie voorheen daar was nie. Uiteraard mag dit nie oorhaastig en beterweterig gedoen word nie, maar met die kollektiewe wysheid in die kerk mag daar ook nie teruggedeins word vir nuwe uitdagings nie. Herinterpretasie vereis dikwels 'n nuwe kyk op bestaande konvensies waaroor niemand meer vrae vra nie en wat dreig om mense se lewens te verstik sonder dat hulle dit besef. In hierdie verband wys Borg (2006:194-217) daarop dat die 'breë weg' vir Jesus nie soseer al die vanselfsprekende sondige dinge van die lewe was nie, maar eerder om vasgevang te wees in al die gewone goeie dinge van die lewe wat lojaliteit aan familie, sekuriteit, rykdom, eer en reinheidsrituele hoër ag as gehoorsaamheid aan God. Daarom dat Jesus daarop uit was om konvensionele wysheid op sy kop te keer. Borg (2006) stel dit so:
He [Jesus] saw his contemporaries as preoccupied with their concerns, limited in their vision, captive to their convictions, and embedded in convention. What was true then seems still to be the way things are for most of us most of the time. (p. 217)

Teen hierdie agtergrond kan ons sê dat die debat ons vandag uitdaag om evangeliese waardes hoër as die konvensionele wysheid van 'n natuurlike aversie aan homoseksualiteit te ag. Dit is net moontlik dat die normalisering van selfdegeslagverhoudings so 'n nuwe uitdaging is.

Die slotsom van ons beredenering van 1:26-27 is dat dit die hermeneutiese insigte is wat in die debat die deurslag gee en nie soseer die eksegese nie. Tog is dit ook so dat wanneer die hermeneutiek sy volle loop geneem het, die eksegetiese argument van perverse homoseksuele dade gepleeg deur heteroseksuele 'n sterk stukrag ontvang, beide vanuit die ervaring van die Christen-homoseksuele van vandag omtrent hulle eie seksuele identiteit asook vanuit die beskrywing in die teks self. Gewoonlik kan kernhomoseksuele glad nie identifiseer met die beskrywing van die soort homoseksuele perversiteit wat deur Paulus in 1:26-27 beskryf word nie. In ons besinning oor die kerk se akkommodering van Christenhomoseksuele sal die kerk ten minste met hierdie werklikhede ernstig rekening moet hou.

\section{Erkenning Mededingende belange}

Die outeur verklaar dat hy geen finansiële of persoonlike verbintenis het met enige party wat hom nadelig kon beïnvloed het in die skryf van hierdie artikel nie.

\section{Literatuurverwysings}

Academy of Science of South Africa, 2015, Diversity in Human Sexuality: Implications for Policy in Africa, viewed 20 April 2016, from http://www.assaf.org.za/8-JuneDiversity-in-human-sexuality1.pdf

Achtemeier, P.J., 1985, Romans, John Knox Press, Atlanta.

Algemene Sinode NG Kerk, 2015, 'Selfdegeslagverhoudings', besoek 20 April 2016, by http://ngkerk.org.za/wp/wp-content/uploads/2013/05/BESLUITE-OORSELFDEGESLAGVERHOUDINGS-ALGEMENE-SINODE-2015.pdf

APA, 2000, Position Statement on Therapies Focused on Attempts to Change Sexual Orientation (Reparative or Conversion Therapies); Position Statement on Psychiatric Treatment and Sexual Orientation; Position Statement on Therapies Focused on Attempts to Change Sexual Orientation (Reparative or Conversion Therapies): SUPPLEMENT; Position Statement on Issues Related to Homosexuality, Therapies): SUPPLEMENT; Position Statement on Issues Related
viewed 20 April 2016, from http://www.psychiatry.org/home

ASSAf, 2015 see Academy of Science of South Africa

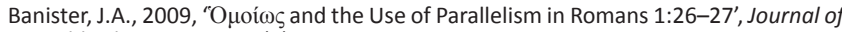
Biblical Literature 128(3), 569-590.

Borg, M., 2006, Jesus: Uncovering the Life, Teachings, and Relevance of a Religious Revolutionary, SPCK, London.

Bornkamm, G., 1986, Paul, Hodder \& Stoughton, London.

Boswell, J., 1980, Christianity, Social Tolerance and Homosexuality, University of Chicago Press, Chicago.

Botha, P.H. \& Janse van Rensburg, F., 2004, "Homosexuality as "Against Nature": An Interpretation of Romans 1:26-27', Acta Patristica et Byzantina 15, 38-56.

Brownson, J.V., 2013, Bible, Gender, Sexuality. Reframing the Church's Debate on Same-Sex Relationships, Eerdmans, Grand Rapids.

Countryman, L.W., 1988, Dirt, Greed and Sex: Sexual Ethics in the New Testament and their Implications for Today, Fortress, Philadelphia.

Cranfield, C.E.B., 1975, A Critical and Exegetical Commentary on the Epistle to Romans, 2 vols., T\&T Clark, Edinburgh. (International Critical Commentary).

Davies, M., 1995, 'New Testament Ethics and Ours: Homosexuality and Sexuality in Romans 1:26-27', Biblical Interpretation 3(3), 315-331. 
De Villiers, E., 2007, 'Kruispunte in Christene se Besluitneming oor Homoseksualiteit', in C. Vos \& D. Human (reds.), Liefde is die Grootste: Oor Erotiek en Seksualiteit, bl. 282-289, Protea Boekhuis, Pretoria.

Debel, H., 2009. “'Unnatural Intercourse” in Rom. 1,26-27: Homosexual or Heterosexual?', in U. Schnelle (ed.) The Letter to the Romans, pp. 631-640, Peeters, Leuven. (Bibliotheca Ephemeridum Theologicarum Lovaniensium CCXXVI).

DeSilva, D.A. 2004, An Introduction to the New Testament: Contexts, Methods \& Ministry Formation, InterVarsity Press, Downers Grove, IL.

Dozeman, T.B., 1995, 'Creation and Procreation in the Biblical Teaching on Homosexuality', Union Seminary Quaterley Review 49(3-4), 169-191.

Du Toit, A.B., 2003, 'Paul, Homosexuality and Christian Ethics', in D. Aune, T. Seland \& J.H. Ulrichsen (eds.), Neotestamentica et Philonica. Studies in Honor of Peder Borgen, pp. 92-107, Brill, Leiden. (Supplements to Novum Testamentum, vol. CVI).

Du Toit, A.B., 2006, 'Etiek en Etos in Romeine', Nederduits Gereformeerde Teologiese Tydskrif 47(3\&4), 443-454.

Du Toit, A.B., 2007, 'Maar die Grootste hiervan is die Liefde', in C. Vos \& D. Human (reds.), Liefde is die Grootste. Oor Erotiek en Seksualiteit, bl. 161-171, Protea Boekhuis, Pretoria.

Dunn, J.D.G., 1988, Romans 1-8, Word Books, Dallas. (Word Biblical Commentary 38A).

Fitzmyer, J., 1993, Romans: A New Translation with Introduction and Commentary, Doubleday, New York. (The Anchor Bible 33).

Hays, R.B., 1986, 'Relations Natural and Unnatural: A Response to John Boswell's Exegesis of Romans 1', The Journal of Religious Ethics 14(1), 184-215.

Hays, R.B., 1996, The Moral Vision of the New Testament: Community, Cross, New Creation: A Contemporary Introduction to New Testament Ethics, Harper One, New York.

Hultgren, A.J., 1994, 'Being Faithful to the Scriptures: Romans 1:26-27 as a Case in Point', Word \& World 14(3), 315-325.

Jewett, R., 2007, Romans: A Commentary, Fortress, Minneapolis. (Hermeneia).

Kalin, E.R., 2003, 'Romans 1:26-27 and Homosexuality', Currents in Theology and Mission 30(6), 423-432.

Kuhn, K.A., 2006, 'Natural and Unnatural Relations between Text and Context: A Canonical Reading of Romans 1:26-27', Currents in Theology and Mission 33(4), 313-329.

Lenow, E., 2006, 'Exchanging the Natural for the Unnatural: Homosexuality's Distortion of God's Design', Southwestern Journal of Theology 49(1), 31-47.

Loader, W., 2014, 'Same-sex relationships: A 1st-century perspective', HTS Teologiese Studies/Theological Studies 70(1), 1-9. Art. \#2114, 9 pages. http://dx.doi. org/10.4102/ hts.v70i1.2114

Malick, D.E., 1993, 'The Condemnation of Homosexuality in Romans 1:26-27', Bibliotheca Sacra 150 (Jul-Sept), 327-340.

McDonald, L.M. \& Porter, S.E., 2000, Early Christianity and its Sacred Literature, Hendrickson, Peabody.

Miller, J.E., 1995, 'The Practices of Romans 1:26: Homosexual or Heterosexual?', Novum Testamentum 37, 1-11.
Miller, J.E., 1997, 'Response: Pederasty and Romans 1:27: A Response to Mark Smith' Journal of the American Academy of Religion 65(4), 861-865.

Moo, D.J., 1996, The Epistle to the Romans, Eerdmans, Grand Rapids. (New International Commentary on the New Testament).

Nolland, J., 2000, 'Romans 1:26-27 and the Homosexuality Debate', The Journal of Religious Ethics 22(1), 32-57.

Phipps, W.E., 2002, 'Paul on 'Unnatural' Sex', Currents in Theology and Mission 29(2), 128-131.

Punt, J., 2006, 'The Bible in the Gay-debate in South Africa: Towards an Ethic of Interpretation', Scriptura 93, 419-431.

Republic of South Africa, 2006, Civil Union Act (Act 17 of 2006), Government Printer, Pretoria.

Ridderbos, H., 1959, Aan de Romeinen, Kok, Kampen. (Commentaar op het Nieuwe Testament).

Schmidt, H.W., 1966, Der Brief des Paulus an die Römer, Evangelische Verlagsanstalt Berlin. (Theologscher Handkommentar zum Neuen Testament, 6)

Schneiders, S.M., 1999, The Revelatory Text: Interpreting the New Testament as Sacred Literature, The Liturgical Press, Collegeville, Mn.

Schreiner, T.R., 1998, Romans, Baker Academic, Grand Rapids. (Baker Exegetical Commentary on the New Testament).

Scroggs, R., 1983, The New Testament and Homosexuality, Fortress, Philadelphia.

Smith, M.D., 1996, 'Ancient Bisexuality and the Interpretation of Romans 1:26-27', Journal of the American Academy of Religion 64(2), 223-256.

Steyn, G.J., 2007, 'Riglyne vir die Verstaan van Homoseksualiteit binne die Konteks van die Nuwe Testament', in C. Vos \& D. Human (reds.), Liefde is die Grootste. Oor Erotiek en Seksualiteit, bl. 172-204, Protea Boekhuis, Pretoria.

Townsley, J., 2013, 'Queer Sects in Patristic Commentaries on Romans 1:26-27: Goddess Cults, Free Will and "Sex Contrary to Nature"?' Journal of the American Academy of Religion 81(1), 56-79.

Van Zyl, H.C., 2002, 'Die Nuwe Testament en Seksualiteit', Acta Theologica 22(2), 234-261.

Vorster, J.N., 2006, 'The Making of Male Same-Sex in the Graeco-Roman World and its Implications for the Interpretation of Biblical Discourses', Scriptura 93, 432-454.

Ward, R.B., 1997, 'Why Unnatural? The Tradition behind Romans 1:26-27', Harvard Theological Review 90(3), 263-284.

Warnich, L., 2015, 'Perspektief vanuit Genetika', referaat gelewer by Eendag konferensie oor Selfdegeslag Verhoudinge, Fakulteit Teologie, Universiteit van Stellenbosch, 12 November 2015, besoek 20 April 2016, by https://www.youtube. com/watch?v=UNaiAqY7FzA\&list=PLm9dcbgaBOrTjwgUE71HiWZ2jcORc10KW\& ndex $=7$

Wilckens, U., 1980, Der Brief an die Römer, Benziger Verlag, Zürich. (Evangelisch Katholischer Kommentar zum Neuen Testament VI/2).

Witherington, B. III, 2004, Paul's Letter to the Romans: A Socio-Rhetorical Commentary, Eerdmans, Grand Rapids. 